\title{
ORGANIZATIONAL CHANGE READINESS PADA UNIVERSITAS X
}

\author{
Azhar El Hami \& Zahrotur Rusyda Hinduan \\ Universitas Padjadjaran, Jl. Raya Bandung-Sumedang KM 21, Jatinangor, 45363 \\ e-mail: azharelhami@gmail.com
}

\begin{abstract}
This study was aimed to capture the readiness to change of the " $X$ " University as an organization regarding to the vision is becoming a world class university. Using the organizational change readiness concept by Sutanto (2008) that covering 7 aspects namely perception toward change, vision of change, mutual trust and respect, change initiative, management support, acceptance, and organization manages the change process. Respondent was 121 employees of the University ' $X$ ' from two faculties who met the criterion. This was a quantitative research that using survey method. The result has shown that two aspects namely vision of change and acceptance were important ones that have effect on organizational change readiness of the " $X$ " university.
\end{abstract}

Keywords: organizational change readiness, world class university, vision.

\begin{abstract}
Abstrak
Penelitian ini bermaksud melihat gambaran kesiapan Universitas X sebagai organisasi untuk berubah dikaitkan dengan visinya untuk menjadi world class university. Konsep yang digunakan berdasarkan konsep kesiapan organisasi yang diungkapkan oleh Sutanto (2008) yang terdiri dari 7 aspek, yaitu: persepsi tentang perubahan, visi perubahan, saling percaya dan menghargai, inisiatif berubah, dukungan menejemen, penerimaan, dan pengelolaan proses perubahan. Subyek penelitian ini adalah para pegawai di Universitas X sebanyak 121 orang dari dua fakultas yang telah memenuhi kriteria yang dipersyaratkan. Desain penelitian yang digunakan adalah penelitian kuantitatif dengan metoda survey. Hasil penelitian memperlihatkan bahwa dua aspek perubahan yaitu, vision of change dan acceptance menjadi aspek penting yang dapat menentukan kesiapan universitas X untuk melakukan perubahan.
\end{abstract}

Kata kunci: kesiapan organisasi untuk berubah, world class university, visi

\section{PENDAHULUAN}

Sebuah organisasi dituntut untuk selalu berubah mengikuti perubahan yang terjadi di lingkungan tempat organisasi tersebut berada. Berbagai tantangan dan persaingan yang terus berkembang di lingkungan menjadi bagian yang harus dihadapi oleh sebuah organisasi. Perubahan ini menjadi sangat penting dilakukan agar organisasi tersebut dapat terus bertahan dan berkembang. Kesiapan organisasi untuk berubah menjadi faktor penting.

Universitas $\mathrm{X}$ sebagai salah satu perguruan tinggi negeri di Indonesia sejak tahun 2008 telah melakukan banyak perubahan. Dimulai dengan pergantian rektor yang kemudian menetapkan visi Universitas X sebagai world class University. Dalam pidato dies natalis yang dikutip dari situs perguruan tinggi tersebut, Rektor Universitas X menekankan pada tujuh hal penting dalam pengelolaan, yaitu penjalinan kerjasama internasional dengan berbagai universitas luar negeri, peningkatan kualitas layanan melalui pembenahan standard operational prosedure, persiapan universitas menjadi BLU, pelayanan wisuda, pelayanan registrasi mahasiswa melalui kerja sama dengan perbankan dan Finnet, pengembangan bandwidth universitas, 
peningkatan kualitas SDM, biaya pendidikan mahasiswa baru, beasiswa. Beberapa program, termasuk prestasi mahasiswa di dalam dan luar negeri, peminat Universitas $\mathrm{X}$ di jalur SNMPTN, ratio dosen dan mahasiswa, peningkatan IPK, proporsi penyelenggaraan pendidikan $\mathrm{S}-1, \mathrm{~S}-2, \mathrm{~S}-3$ dan D-III, program kerja alumni, program penelitian, dan berbagai pengembangan fasilitas.

Dalam pelaksanaannya masih belum berjalan dengan lancar. Implementasi dari perubahan kebijakan belum dapat terlaksana sesuai dengan yang diharapkan. Perubahan sistem kerja yang desentralisasi menjadi sistem sentralisasi menimbulkan beberapa permasalahan-permasalahan administrasi yang menggangu kelancaran kegiatan belajar-mengajar. Hal ini menjadi keluhan tersendiri bagi tenaga administrasi di fakultas. Misalnya saja perubahan kebijakan pendataan mahasiswa yang pada awalnya dilaksanakan oleh masing-masing fakultas namun sekarang penyelenggaranya dilakukan oleh pihak rektorat dengan menggunakan sistem online. Kendala yang dihadapi oleh fakultas A adalah terkait dengan keterlambatan penerimaan data-data mahasiswa yang mengikuti perkuliahan serta ketidakakuratan data-data pun sering terjadi. Daftar mahasiswa yang belum melakukan registrasi ulang pun tak jarang terlambat diberitahukan sehingga menyulitkan fakultas untuk bisa mengetahui mahasiswamahasiswa yang berhak mengikuti perkuliahan sehingga mengganggu kegiatan belajar mengajar. Tidak jarang pula, nama mahasiswa tidak tercantum hingga akhir semester. Kondisi ini berbeda dengan ketika sistem pendataan masih dilakukan oleh tiap-tiap fakultas.

Kesulitan registrasi pun terjadi terutama bagi mahasiswa yang telah diberikan kesempatan untuk memperpanjang masa studinya. Pihak rektorat telah memutuskan memberikan kesempatan untuk menambah waktu penyelesaian kuliah bagi mahasiswa yang telah mencapai batas akhir studi dengan catatan mahasiswa tersebut dapat menyelesaikan studinya dalam kurun waktu tertentu. Namun terjadi perlakuan berbeda ketika mahasiswa melakukan registrasi ulang. Sejumlah mahasiswa dari suatu fakultas tidak dapat melakukan registrasi ulang dengan alasan telah melebihi masa studinya, sementara sejumlah mahasiswa lainnya dari fakultas yang sama dapat melakukan registrasi. Penjelasan yang diterima mahasiswa mengenai aturan ini berbeda antara satu pegawai dengan pengawai lainnya di bagian akademik universitas. Pihak kepala urusan akademik tidak dapat memberikan keputusan mengenai kondisi ini dan harus berkonsultasi dengan Pembantu Rektor. Hal ini membuat permasalahan ini menjadi berlarut-larut sehingga mahasiswa yang mendapatkan kesempatan untuk melanjutkan studi pun tidak dapat memenuhi target waktu penyelesaian yang telah ditetapkan.

Sementara itu terkait dengan pengembangan kemampuan dan keterampilan SDM, diadakan pelatihan kepada para pegawai administrasi terkait dengan program administrasi yang digunakan di Universitas X. Namun pada kenyataannya hasil dari pelatihan tersebut banyak yang tidak dimanfaatkan. Mereka masih menggunakan sistem kerja yang lama. Misalnya saja pelatihan penggunaan program kesekretariatan di universitas yang berbasis komputer yang terhubung secara on-line bagi seluruh sekretaris di berbagai unit kerja dan fakultas. Namun setelah selesai pelatihan, banyak yang tidak memanfaatkan sistem tersebut dengan alasan tidak terlalu nyaman untuk memanfaatkannya dan dirasakan cukup merepotkan sehingga mereka pun tetap masih menggunakan cara-cara lama. Selain itu, banyak kendala yang dihadapi dalam menggunakan soft ware yang ada, terutama keterandalan koneksi. Hasilnya banyak kegiatan suratmenyurat dari rektorat ke fakultas menjadi terhambat dan berdampak juga pada keterlambatan pengambilan keputusan. 
Perubahan pun terjadi terutama terkait dengan jam kerja yang berlaku bagi seluruh pegawai administrasi di Universitas X. Sebelumnya tidak ada ketetapan jam masuk dan jam kepulangan bagi pegawai, namun saat ini telah diberlakukan jam masuk. Mereka berupaya agar tidak terlambat masuk kerja. Namun ketika telah ditanyakan alasan mereka untuk datang tepat waktu lebih banyak dikarenakan menghindari pemotongan tunjangan transportasi. Sementara untuk waktu kepulangan, tidak banyak terjadi perubahan perilaku dibandingkan dengan sebelumnya. Sebagian besar pegawai administrasi telah melakukan persiapan kepulangan jauh sebelum waktunya sehingga tak jarang ketika dosen membutuhkan peralatan terkait dengan kegiatan belajar mengajar menjadi tidak terlayani. Bahkan pengembalian alat yang menunjang kegiatan belajar mengajar pun menjadi sulit untuk dilakukan dikarenakan pegawai administrasinya telah pulang. Kondisi ini dapat menjadi salah satu penyebab terjadi kehilangan barang yang dimiliki oleh fakultas dalam beberapa kali.

Sementara terkait dengan pengelolaan SDM, salah satu perubahan kebijakannya adalah memperbolehkan para tenaga honorer untuk menempati posisi struktural di fakultas selama ia mampu menjalankan tugasnya. Hal ini membuat suasana kerja pun sedikit berubah. Kesediaan dari pegawai yang lebih senior untuk mendukung bagi penyelesaian tugas-tugas bagi para pejabat yang baru pun menjadi tidak maksimal. Mereka bersedia memberikan informasi terkait dengan tugasnya hanya ketika pejabat baru tersebut bertanya kepada mereka. Situasi ini membuat iklim kerja yang terjadi di fakultas tersebut menjadi kurang kondusif guna terciptanya kerja samanya yang optimal. Belum lagi kekhawatiran kehilangan jabatan pun dirasakan oleh para pegawai yang lebih senior.

Perubahan suasana kerja pun dirasakan seiring dengan terjadinya perubahan akibat kebijakan dari tingkat universitas. Sikap kerja yang kurang peka dan peduli terhadap pekerjaan rekan lainnya sangat dirasakan. Kebijakan dari pihak rektorat terkait dengan berbagai kegiatan fakultas adalah perubahan sistem kerja menjadi sistem kerja kepanitiaan, seperti kepanitiaan sidang, kepanitiaan pengembangan kurikulum, kepanitian lokakarya fakultas dan lain sebagainya. Kepanitian tersebut akan terkait dengan kompensasi yang diterima oleh namanama pegawai yang terdapat didalam kepanitiaan berupa honor dalam jumlah tertentu. Namun pada kenyataannya, tidak semua pegawai yang tercantum dalam kepanitiaan bekerja untuk menyelesaikan kegiatan tersebut. Pihak yang lebih banyak bekerja adalah pegawai-pegawai dengan Tupoksi yang memang terkait langsung dengan kegiatan tersebut. Sementara jumlah kompensasi yang diterima adalah sama antara pegawai yang memang terlibat dari awal hingga akhir kegiatan dengan pegawai yang tidak bekerja sama sekali. Hal ini membuat ketidakpuasan. Misalnya saja pada fakultas A untuk persiapan sidang sarjana, yang lebih banyak bekerja adalah bagian akademik mulai dari persiapan nama-nama mahasiswa yang mengikuti sidang, menghubungi dosen penguji bahkan hingga hari $\mathrm{H}$ pelaksanaan serta penyelesaian rekapitulasi nama-nama mahasiswa untuk yudisium hingga wisuda. Beban kerja yang dirasakan oleh bagian administrasi jauh lebih besar di bandingkan dengan pegawai-pegawai lainnya yang namanya tercantum dalam kepanitiaan. Namun terkait dengan honor besarannya sama, baik yang bekerja maupun tidak bekerja. Belum lagi, banyak pegawai lainnya yang tidak peka dan peduli terhadap keberhasilan suatu kegiatan fakultas, dikarenakan nama mereka tidak tercantum pada kepanitiaan. Mereka merasa bukan tanggung jawab mereka.

Berdasarkan permasalahan yang telah dipaparkan, maka menimbulkan pertanyaan pada peneliti, "seperti apakah 
gambaran kesiapan Universitas X sebagai sebuah organisasi dalam menghadapi perubahan?"

Perubahan lingkungan yang berlangsung secara dinamis, membuat organisasi harus selalu secara terus-menerus melakukan berbagai perubahan baik dalam strategi, struktur, proses dan budaya. Banyak faktor yang memberikan kontribusi terhadap efektivitas perubahan yang terjadi dalam organisasi. Salah satu faktornya adalah readiness for change. Readiness menggambarkan keyakinan, sikap dan tujuan dari para anggota organisasi mengenai seberapa luas perubahan tersebut diperlukan dan kapasitas keberhasilan organisasi dalam melakukan perubahan (A.B. Sutanto, 2008). Hal ini merupakan kecenderungan secara kognitif mengenai perilaku yang ditampilkan, apakah menolak atau mendukung upaya perubahan tersebut (Amenakis, dkk., 1993).

Berdasarkan penelitian, terdapat tujuh aspek dari change readiness, yaitu Persepsi terhadap upaya perubahan (perception toward change efforts), visi untuk berubah (vision for change), rasa saling percaya dan menghargai (mutual trust \& respect), rencana perubahan (change initiatives), dukungan manajemen (management support), penerimaan (acceptance) dan pengelolaan proses perubahan (the organization manage the change process). Pada intinya, kesiapan untuk berubah sangat terkait dengan transformasi kognitif individu pada para pegawai (Amenakis, dkk., 1993). Kunci utama dari perubahan terletak pada manusia sebagai sumber dan penggerak perubahan, karena merekalah yang akan menerima atau menolak suatu perubahan (Smith, 2005).

\section{a. Perception toward change efforts}

Persepsi pegawai terhadap upaya perubahan di dalam organisasi menjadi aspek penting dalam change readiness. Hal ini telah diidentifikasi menjadi salah satu kunci utama untuk memahami sumber penolakan dalam skala yang besar (Eby, dkk., 2000). Persepsi ini dapat menjadi fasilitas ataupun kendala bagi efektifitas suatu intervensi dalam perubahan (Armenakis, dkk., 1993; Lewin, 1951). Pegawai sebagai target perubahan menjadi sumber utama bagi keberhasilan, karena sikap, keterampilan, motivasi dan bentuk pemahaman dasar membentuk komponen dasar dari lingkungan organisasi yang akan diubah (Smith, 2005).

Persepsi akan mempengaruhi sikap dan perilaku dalam menghadapi perubahan. Pengalaman masa lalu, akan mempengaruhi proses dalam menginterpretasi informasi melalui proses kognitif pada individu. Persepsi pegawai terhadap keberhasilan perubahan di masa lalu juga akan mempengaruhi kesiapan terhadap perubahan. Informasi yang terkait dengan perubahan akan diasosiasikan dengan pengalaman masa lalu dari masing-masing individu dengan memberikan atribusi terhadap upaya-upaya perubahan. Individu memiliki pandangan yang tetap mengenai sejauh mana kesiapan organisasi untuk berubah. Persepsi ini akan berkembang terus menerus seiring dengan perkembangan individu ketika menjadi bagian dari sejarah organisasi (Eby, dkk., 2000). McDonald dan Siegal (1993), Lacovini (1993), dan McManus, dkk. (1995) mengusulkan bahwa sikap pegawai terhadap suatu perubahan akan berdampak pada moral kerja, produktifitas dan keinginan karyawan untuk keluar dari organisasi (Eby, dkk., 2000).

Sementara itu, persepsi pegawai terhadap fleksibilitas perusahaan dalam menghadapi perubahan juga menjadi hal yang sangat penting. Persepsi pegawai terhadap kemampuan organisasi untuk mengakomodasi perubahan situasi dengan memberikan alternatif kebijakan dan prosedur kerja sangat terkait dengan kesiapan untuk berubah. (Eby, dkk., 2000). Persepsi pegawai terhadap tingkat fleksibilitas organisasi mereka 
untuk menerima perubahan serta seberapa luas mereka dapat berperan serta secara aktif dalam proses tersebut, menjadi faktor penting bagi keberhasilan perubahan (Smith, 2005).

\section{b. Vision for Change}

Sebuah visi akan menjadi ketetapan dan kejelasan arah dari sebuah organisasi untuk maju. Tanpa visi yang realistis, upaya transformasi akan berubah menjadi kebingungan dan menjadi proyek yang tidak sesuai bahkan dapat mendorong organisasi ke arah yang salah atau tidak terarah sama sekali (Kotter, 1995). Oleh karenanya, pemahaman yang menyeluruh dari para pegawai terhadap visi dari perusahaan/organisasi serta visi dari perubahan menjadi sangat penting. Kotter (1995) juga menekankan pada pentingnya menciptakan sebuah visi mengenai perubahan tersebut, menjelaskan kepada orang lain mengenai alasan diperlukannya perubahan dan cara untuk mencapainya (Smith, 2005). Martin (1993) dan Terry (2001) menekankan bahwa sebuah visi menjadi bagian yang penting dari proses perubahan, namun para pemimpin perlu menyadari bahwa sebuah visi harus diberikan secara langsung kepada para pegawai (Stadtlander, 2006).

Orang dalam organisasi harus memiliki kesamaan aspirasi terhadap perubahan yang akan berlangsung. Strebel (1996) menyatakan bahwa kegagalan sebuah proses perubahan banyak disebabkan oleh perbedaan pemahaman akan visi antara pemimpin dan pegawai. Bagi para pemimpin, perubahan berarti kesempatan baik secara bisnis maupun bagi dirinya sendiri. Namun bagi para pegawai, perubahan dipandang sebagai gangguan dan menekan (Stadtlander, 2006). Melalui peran aktif dan terlibat secara nyata dalam proses perubahan, seseorang akan dapat membantu dirinya untuk melihat keterkaitan antara pekerjaan dan sikapnya dengan performa organisasi secara menyeluruh. Hal ini pula dapat mendorong bagi rasa tanggung jawab pribadi untuk mencapai perubahan tersebut (Smith, 2005). Valensi pribadi antara kejelasan mengenai keuntungan secara intrinsik maupun ekstrinsik, dapat membantu bagi perkembangan momentum perubahan. Secara spesifik, ketika pegawai melihat bahwa perubahan akan menguntungkan bagi dirinya, maka mereka akan memulai untuk mencari cara guna mengembangkan dan mengatasi masa transisi (Bernerth, 2004).

\section{c. Mutual trust and respect}

Kesiapan dan kemampuan individu maupun organisasi untuk berubah seharusnya didasari oleh saling percaya dan menghargai. Adalah hal yang penting bahwa rasa percaya yang cukup akan membuat para staf untuk secara terbuka mengekspresikan pandangannya dan berkrompomi secara demokratis. Cummings dan Huse (1989), menyatakan bahwa rasa saling percaya tersebut tidak hanya terhadap pihak manajemen, namun juga terhadap rekan kerjanya (Eby dkk., 2000).

Rasa saling menghargai dan percaya menjadi dasar yang penting bagi efektifitas dalam tim kerja. Sundstrom dkk. (1990) menyatakan bahwa organisasi mengembangkan implementasi kerja sama tim dengan berbagai alasan yang berbeda, yaitu memenuhi kebutuhan pelanggan, mengembangkan inovasi dan meningkatkan produktifitas organisasi (Eby dkk., 2000). Ia dan Goodman, dkk. (1988) menemukan bukti bahwa kerja sama tim dapat mengembangkan berbagai outcome organisasi pada situasi yang kondusif. Goodman, dkk. (1988), Cohen \& Bailey (1997) menemukan hubungan antara outcome dengan pemanfaatan kerja sama tim, termasuk sikap yang menyenangkan serta indikator quality of work life 
lainnya, serta peningkatan produktivitas dan efektifitas organisasi secara menyeluruh (Eby dkk., 2000).

\section{d. Change initiative}

Organisasi selalu dihadapkan pada kebutuhan untuk mengimplementasikan perubahan pada strategi, struktur, proses dan budaya (Armenakis, dkk., 1993). Hal ini disebabkan oleh perkembangan dunia yang sangat kompleks, sebagai hasil dari saling keterkaitan antara satu dengan yang lainnya di dunia secara ekonomi. Pada saat yang sama, dunia pun berkembang secara dinamis sebagai hasil dari derasnya informasi dan perkembangan komunikasi dunia (Zeffane, 1996). Tanpa perubahan, organisasi akan sulit bertahan. Tanpa pengenalan terkait dengan perubahan yang adekuat baik secara waktu dan etika, organisasi akan dihadapkan pada kesulitan untuk mengejar ketinggalan dan mengurangi kesempatan mereka untuk dapat bertahan dalam jangka waktu yang panjang (Christian dan Stadtlander, 2006).

Banyak keberhasilan dalam perubahan diawali oleh sejumlah individu atau beberapa grup yang berusaha untuk melihat para pesaing, posisi pasar, tren teknologi dan performa secara finansial. Lalu kemudian mereka berupaya untuk mengkomunikasikan temuan, terutama hal-hal yang bersifat kritis atau bahkan kesempatan yang besar. Langkah pertama ini menjadi sangat penting karena upaya untuk memulai proses transformasi membutuhkan kerja sama dari berbagai individu (Kotter, 1995).

Seluruh anggota organisasi seharusnya memiliki kewenangan untuk memberikan usulan atau inisiatif dalam perubahan. Tapi tetap pada akhirnya, pemimpin organisasi yang menentukan perubahan yang diperlukan. Pemimpin organisasi pada dasarnya menjadi pemimpin karena mereka memiliki ke- mampuan dalam perencanaan dan membayangkan serta mengkomunikasikan mengenai masa depan organisasi (Zeffane, 1996). Walau demikian, orang-orang dalam organisasi juga harus diberikan kesempatan untuk terlibat dalam seluruh aspek perubahan dan memberikan kesempatan kepada mereka untuk memberikan umpan balik (Waddel dan Sohal, 1998).

Sumber daya manusialah yang akan mewujudkan cita-cita organisasi dan mereka adalah sumber utama dan penggerak bagi proses perubahan. Mereka pulalah yang akan mendukung atau menolak perubahan tersebut. Pada kenyataannya, orang tidak akan menolak perubahan, jika perubahan tersebut jelas dan memberikan manfaat bagi mereka (Waddel dan Sohal, 1998). Jika perubahan organisasi tersebut dipahami oleh pegawai, maka organisasi dan orang dalam organisasi tersebut siap untuk bertransformasi (Smith, 2005).

\section{e. Management support}

Dukungan dari manajemen terhadap upaya perubahan merupakan faktor penting lainnya dalam menciptakan kesiapan dalam menghadapi perubahan. Armenakis, dkk. (1993) menemukan bahwa tingkat dukungan manajemen berupa kebijakan dan aturan menjadi hal yang penting dalam upaya memahami bagaimana para pegawai melihat kesiapan organisasi untuk berubah (Eby, dkk., 2000). Menurut Beckhardt dan Harris (1987), serta Schneider, dkk. (1992), dalam Eby dkk. (2000), hal ini juga termasuk fleksibilitas kebijakan dan prosedur, logistik dan dukungan sistem yang berlaku. Disamping itu, Armenakis, dkk. (1993), McManus, dkk. (1995) juga menemukan bahwa tingkat kepercayaan manajemen dapat memunculkan persepsi yang positif terhadap kecepatan organisasi dalam menghadapi perubahan (Eby dkk., 2000). 
Dukungan terhadap perubahan seharusnya tercermin dari efektifitas perubahan kepemimpinan. Kepemimpinan yang efektif ini terkait dengan pengawasan terhadap perubahan, melakukan koreksi dalam proses perubahan dan mengetahui waktu yang tepat untuk visi yang baru. Untuk dapat memimpin dan mengelola strategi perubahan, sangat dibutuhkan kemampuan untuk belajar dan beradaptasi dengan perubahan. Pada prosesnya, organizational learning terbentuk pada lingkungan yang terbuka dan saling percaya sehingga memberikan kesempatan kepada orang untuk bisa menerima dan mengalami perubahan tanpa ada perasaan terancam (Zeffane, 1996).

Bentuk lainnya terhadap dukungan manajemen dalam upaya perubahan organisasi tercermin dari pembentukan tim yang spesial. Tim ini bertanggung jawab guna melakukan analisis terhadap situasi yang berpengaruh baik secara internal maupun eksternal, merencanakan proses perubahan dalam bentuk yang lebih detail, mengidentifikasi kemungkinan resiko dan tindakan antisipasi serta mengendalikan pelaksanaan termasuk melakukan evaluasi dan mengarahkan penyesuaian terhadap situasi nyata.

\section{f. Acceptance}

Perubahan seharusnya dapat menjadikan performa organisasi meningkat. Meski demikian, bagi beberapa orang, perubahan dapat menciptakan perasaaan kegelisahan dan ketegangan, dan pada awal proses perubahan, anggota organisasi merasakan ketidakpastian dan kebingungan (Bernerth, 2004). Karena perubahan organisasi tercirikan dengan dampak dari terselesaikannya suatu pekerjaan, maka reaksi dari pegawai terhadap proses perubahan menjadi hal yang sangat penting (Eby, dkk., 2000).

Pegawai dapat menerima perubahan jika mereka merasa bahwa dengan berubah memberikan manfaat bagi mereka. Meski demikian, beberapa pegawai tidak menyadari manfaat dan keuntungan secara finansial dari perubahan tersebut. Mereka hanya peduli terhadap hasil akhir yang cepat. Pada sisi lain, keuntungan pada proses perubahan pada dasarnya dapat dinikmati sepanjang waktu. Pengembangan pemahaman mengenai dasar dan alasan dari suatu perubahan dapat menjadi langkah awal bagi kesediaan dari pegawai untuk bersedia mengambil resiko dan berani mengatasi berbagai hambatan (Smith, 2005).

Perencanaan yang baik terhadap suatu perubahan tidak dapat terlaksana tanpa adanya dukungan kemampuan dan komitmen dari agen perubahan. Beckard dan Harris (1987) memberikan penjelasan bahwa reshaping capabilities suatu organisasi membutuhkan pengetahuan, keterampilan, dan kemampuan yang menyeluruh dari organisasi tersebut untuk dapat mencapai keberhasilan dari pelaksanaan perubahan (Jones, dkk., 2005). Turner dan Crawford (1998) memberikan suatu ide bahwa organizational capabilities perlu mengalami perubahan. Mereka mengusulkan suatu taksonomi yang terdiri dari keterlibatan (engagement), pengembangan (development) dan manajemen performa (performance management). Keterlibatan (engagement) adalah kesediaan dari para anggota organisasi untuk selalu saling memberikan informasi dan terlibat dalam upaya untuk mendorong munculnya suatu motivasi dan komitmen terhadap tujuan organisasi. Pengembangan (development) termasuk didalamnya pengembangan semua sumber daya dan sistem yang diperlukan untuk mencapai arah masa depan organisasi. Tindakan proaktif dalam pengelolaan berbagai faktor yang dapat mendorong bagi performa organisasi agar tetap secara konsisten dan efektif tercapainya perubahan merupakan hal yang dikatakan Turner dan 
Crawford sebagai performance management (Jones, dkk., 2005).

\section{g. Managing change}

Perubahan sebaiknya tidak dulu dilakukan ketika terjadi program yang bertentangan dalam lingkungan organisasi. Melalui program yang berkesinambungan, yaitu seluruh program dan rencana program seharusnya dikelola sejalan dengan program perubahan yang sedang berlangsung. Keyakinan para pemimpin di dalam organisasi untuk bisa mengelola perubahan dalam organisasi menjadi kunci penting bagi pengembangan keyakinan dari para pegawai terhadap keberhasilan program. Mengacu pada Armenakis dan Harris (2001), implementasi perubahan dalam organisasi adalah hal yang sangat penting, namun hal ini pula yang kurang dipahami oleh para pemimpin. Gilmore, dkk. (1997) menemukan bahwa sejumlah organisasi melakukan perubahan yang disebabkan oleh performa organisasi yang tidak meningkat dan munculnya reaksi dari para pegawai yang tidak menyenangkan (Armenakis dan Harris, 2001).

Keyakinan suatu organisasi untuk bisa mengatasi berbagai tantangan dalam menghadapi perubahan menunjukkan kesiapan organisasi tersebut untuk berubah. Sumber potensial hambatan terhadap proses perubahan telah teridentifikasi dan terantisipasi. Pardo del Val dan Fuentes (2003) mengidentifikasi 5 hal yang menjadi sumber penghambat, yaitu direct cost of change (Rumelt, 1995); cannibalization costs, mengubah sesuatu yang dapat menunjang bagi keberhasilan terhadap suatu produk, namun di sisi lain membuat kerugian terhadap hal yang lain, oleh karenanya dibutuhkan pengor-banan (Rumelt, 1995); cross subsidy comforts, karena kebutuhan perubahan dikompensasikan dengan pencapaian yang tinggi tanpa perubahan dengan faktor yang berbeda, maka pada dasarnya tidak ada motivasi yang nyata dalam perubahan (Rumelt, 1995); past failures, tentunya meninggalkan rasa pesimis tentang gambaran masa depan (Lorenzo, 2000); dan different interests diantara pegawai dengan manajemen, atau kesenjangan motivasi antara pegawai dengan nilai perubahan yang lebih kecil jika dibandingkan dengan para manajernya (Waddell dan Sohal, 1998).

\section{METODE PENELITIAN}

Metoda penelitian yang digunakan pada penelitian ini adalah metoda survey. Sebuah kuesioner kuantitatif berdasarkan teori yang telah dipaparkan sebelumnya akan digunakan dalam pengukuran ini. Survey ini bersifat self-completed namun terstruktur, dengan nama dari responden akan dirahasiakan. Hal ini dilakukan agar para responden dapat secara bebas mengekspresikan pemikirannya. Responden dipilih secara free sampling.

Adapun partisipan dari penelitian ini adalah pegawai Universitas $\mathrm{X}$ baik tenaga Akademik maupun non-akademik dengan kriteria telah berada di Universitas $\mathrm{X}$ minimal setelah 3 tahun, yaitu masa ketika perubahan tersebut ditetapkan sehingga diharapkan partisipan dapat menghayati situasi sebelum perubahan dan sesudah perubahan.

Organizational Change Readiness ini diukur melalui suatu skala yang telah dikembangkan peneliti untuk menjaring data-data mengenai kesiapan organisasi untuk berubah. Alat ukur ini terdiri dari 28 item dengan skala antara 1 sampai 4 dengan mengacu pada teori yang disampaikan oleh Sutanto (2008). Menurutnya terdapat 7 dimensi dari kesiapan organisasi untuk berubah, yaitu (1) persepsi terhadap upaya perubahan (Perception Toward Change Efforts - PTCE) yaitu suatu skala yang mengukur tentang bagaimana keyakinan pegawai terhadap perubahan yang terjadi pada organisasinya, (2) 
visi untuk berubah (Vision for change $V O C$ ) yaitu suatu skala yang mengukur tentang tingkat pemahaman pemahaman pegawai tentang visi dari perubahan. Sementara itu, (3) rasa saling percaya dan menghargai (Mutual Trust \& Respect $M T R$ ) yaitu suatu skala yang mengukur tingkat kepercayaan dan kesediaan para pegawai untuk bekerja sama, termasuk atasan, (4) inisiatif untuk melakukan perubahan (Change Initiatives - CI) yaitu suatu skala yang mengukur tingkat keaktifan dari para anggota organisasi dalam mewujudkan perubahan, (5) dukungan manajemen (Management Support - MS) yaitu suatu skala yang mengukur tingkat dukungan manajemen terhadap perubahan (bisa berupa kebijakan, aturan, sikap pemimpin, kompensasi). (6) Penerimaan (Acceptance - Acc) adalah suatu skala yang mengukur tingkat penerimaan dari pegawai terhadap perubahan dan (7) pengelolaan perubahan (The Organization Manage the Change Process - MC) mengacu pada suatu skala yang mengukur tentang tingkat perencanaan pengelolaan perubahan yang dilakukan oleh perusahaan/instansi.

Setelah dilakukan uji coba alat ukur dan dihitung secara statistik mengenai reliabilitas alat ukur (OCR), maka didapatkan hasil sebagai berikut:

Tabel 1. Reliabilitas Alat Ukur OCR

\begin{tabular}{cc}
\hline $\begin{array}{c}\text { Uji } \\
\text { Reliabilitas }\end{array}$ & Coba \\
Keseluruhan OCR & $\begin{array}{c}\text { Angka } \\
\text { Reliabilitas }\end{array}$ \\
\hline Aspek 1 - PTCE & 0,917 \\
Aspek 2 - VoC & 0,700 \\
Aspek 3 - MTR & 0,623 \\
Aspek 4 - CI & 0,705 \\
Aspek 5 - MS & 0,601 \\
Aspek 6 - Acc & 0,705 \\
Aspek 7 - MC & 0,638 \\
\hline
\end{tabular}

Jika dibandingkan dengan kriteria Guilford (1979) maka pada dasarnya baik reliabilitas alat ukur OCR secara keselu- ruhan maupun aspek-aspek yang terdapat didalam OCR dapat diandalkan. Reliabilitas alat ukur secara keseluruhan termasuk dalam kategori tinggi sekali $(0,9<$ ac $<$ 1,0). Jika dilihat pada masing-masing aspek, maka reliabilitas untuk aspek MTR (Mutual Trust \&Respect), MS (Managing Support) dan MC (Managing Change) tergolong tinggi $(0,7<$ ac $<0,9)$. Sementara untuk aspek PTCE (Perception Toward Change Effort0, VoC (Vision of Change), CI (Change Initiative) dan Acc (Acceptance) berada pada kategori sedang $(0,4<$ ac $<0,7)$. Sedangkan untuk uji validitas, alat ukur ini menggunakan kriteria expert judgment, sehingga diharapkan bahwa item-item yang ada dapat mengukur kesiapan organisasi dalam menghadapi perubahan.

Sementara itu, untuk menentukan kriteria Ready - not Ready maupun masing-masing aspek maka dibuat suatu norma berdasarkan norma kelompok pada Universitas $\mathrm{X}$ yang diambil dari keseluruhan data OCR dari kedua fakultas yang menjadi sampel penelitian.

Berdasarkan perhitungan mean sebagai pembeda kriteria OCR, maka didapatkan hasil sebagai berikut:

Tabel 2. Norma Kelompok OCR

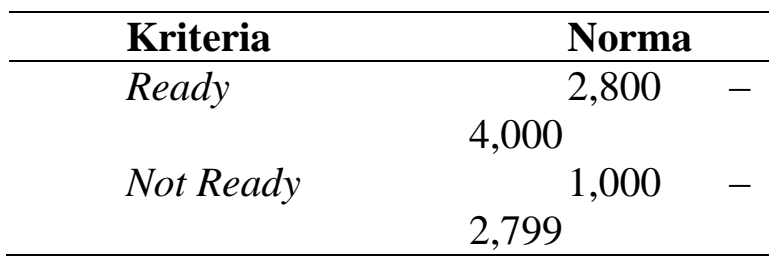

Adapun norma untuk masing-masing aspek OCR dan kriterianya adalah seperti tabel 3 : 
Tabel 3. Norma Kelompok Aspek-aspek OCR

\begin{tabular}{|c|c|c|c|}
\hline No & Aspek & Kriteria & Norma \\
\hline \multirow{2}{*}{1.} & Perception $\quad$ Toward & Yakin & $2,938-4,000$ \\
\hline & Change Effort (PTCE) & Ragu-ragu & $1,000-2,937$ \\
\hline \multirow{2}{*}{2.} & \multirow{2}{*}{ Vision of Change (VoC) } & Paham & $2,841-4,000$ \\
\hline & & Tidak Paham & $1,000-2,840$ \\
\hline \multirow{2}{*}{3.} & \multirow{2}{*}{$\begin{array}{l}\text { Mutual Trust \& Respect } \\
\text { (MTR) }\end{array}$} & Kooperatif & $2,826-4,000$ \\
\hline & & Tidak Kooperatif & $1,000-2,825$ \\
\hline \multirow{2}{*}{4.} & \multirow{2}{*}{ Change Initiative $(\mathrm{CI})$} & Aktif & $2,616-4,000$ \\
\hline & & Pasif & $1,000-2,615$ \\
\hline \multirow{2}{*}{5.} & \multirow{2}{*}{$\begin{array}{l}\text { Management } \\
\text { (MS) }\end{array}$} & Mendukung & $2,733-4,000$ \\
\hline & & Tidak Mendukung & $1,000-2,732$ \\
\hline \multirow{2}{*}{6.} & \multirow{2}{*}{ Acceptance (Acc) } & Menerima & $2,926-4,000$ \\
\hline & & Menolak & $1,000-2,925$ \\
\hline \multirow{2}{*}{7.} & \multirow{2}{*}{ Managing Change } & Terencana & $2,719-4,000$ \\
\hline & & Tidak terencana & $1,000-2,718$ \\
\hline
\end{tabular}

\section{HASIL DAN PEMBAHASAN}

Setelah dilakukan pengambilan data terhadap para pegawai di Universitas $\mathrm{X}$ dengan mengambil sampel dua fakultas (fakultas A dan fakultas B) maka didapatkan jumlah total responden sebanyak 121 orang, dengan komposisi fakultas A sebanyak 67 orang dan fakultas B sebanyak 54 orang. Adapun gambaran dari responden pada kedua fakultas yang menjadi sampel penelitian adalah seperti tabel 4:

Untuk jenis kelamin, relatif kompo- sisinya tidak terlalu jauh berbeda, dimana jumlah responden pria sebanyak 57 orang sedangkan responden wanita 64 orang. Sementara untuk tingkat pendidikan, lebih banyak berasal dari tingkat pendidikan SLTA yaitu sebanyak 38 orang, lalu S2 sebanyak 33 orang dan S1 sebanyak 31 orang. Responden dari fakultas A lebih banyak berpendidikan SLTA/sederajat yaitu sebanyak 22 orang, S2 sebanyak 19 orang, S1 sebanyak 18 orang, 5 orang berpendidikan D3, 2 orang berpendidikan S3 dan 1 orang dengan tingkat pendidikan SLTP. Sedangkan pada fakultas B,

Tabel 4. Gambaran Responden (Jenis Kelamin \& Pendidikan)

\begin{tabular}{|c|c|c|c|c|c|c|c|c|c|}
\hline \multirow{2}{*}{ NO } & \multirow{2}{*}{ FAK } & \multicolumn{2}{|c|}{ Jenis Kelamin } & \multicolumn{6}{|c|}{ Pendidikan } \\
\hline & & Pria & Wanita & SLTP & SLTA & D3 & S1 & S2 & S3 \\
\hline 1. & A & 26 & 41 & 1 & 22 & 5 & 18 & 19 & 2 \\
\hline 2. & B & 31 & 23 & 0 & 16 & 6 & 13 & 14 & 5 \\
\hline & & 57 & 64 & 1 & 38 & 11 & 31 & 33 & 7 \\
\hline
\end{tabular}


sebagian besar responden berpendidikan SLTA sebanyak 16 orang, lalu S2 sebanyak 14 orang, S1 sebanyak 13 orang, D3 sebanyak 6 orang dan 5 orang berpendidikan S3.

Sementara untuk kategori usia, sebagian besar responden dari kedua fakultas baik fakultas A dan fakultas B berada pada usia produktif yaitu kelompok usia 25-35 tahun dan kelompok usia 35-45 tahun. 50 orang berusia antara 35-45 tahun, 45 orang berusia antara 25-35 tahun dan 24 orang berusia antara 45-55 tahun. Pada fakultas A 27 orang dari 67 responden berada pada usia 25-35 tahun, 27 orang lainnya berusia 35-45 tahun dan 13 orang berusia 45-55 tahun. Sementara untuk fakultas B, 23 dari 54 responden berusia 35-45 tahun, 18 orang berusia 2535 tahun, 11 orang berusia 45-55 tahun dan 1 orang masing-masing berusia diatas 65 tahun dan dibawah 25 tahun. Sementara jika dibagi berdasarkan status peker- sebanyak 47 orang, sedangkan sisanya sebanyak 20 orang berstatus sebagai dosen. Fakultas B pun demikian, dengan 34 orang dari 54 responden berstatus sebagai tenaga kependidikan dan sisanya yaitu sebanyak 20 orang berstatus sebagai dosen.

Gambaran masa kerja responden secara umum cukup merata mulai kurang dari 10 tahun (41 orang), 10-20 tahun (49 orang) hingga masa kerja selama 20-30 tahun (39 orang). Responden dari fakultas A, 25 orang diantaranya telah memiliki masa kerja antara 10-20 tahun, 23 orang dengan masa kerja dibawah 10 tahun, 18 diantaranya telah bekerja selama 20-30 tahun dan 1 orang telah bekerja selama lebih dari 30 tahun. Sementara responden dari fakultas B, 24 dari 54 responden telah bekerja selama 10-20 tahun, 18 responden memiliki masa kerja selama kurang dari 10 tahun, 11 orang telah bekerja selama 20-30 tahun dan 1 diantaranya telah bekerja

Tabel 5. Kesiapan Organisasi Untuk Berubah Universitas X

\begin{tabular}{lccl}
\hline \multicolumn{1}{c}{ Aspek } & Skor & Norma & Kategori \\
\hline Organizational Change Readiness & 2,784 & 2,81 & Not Ready \\
Perception Toward Change Effort (PTCE) & 2,919 & 2,93 & Ragu-Ragu \\
Vision of Change (VoC) & 2,826 & 2,93 & Tidak Paham \\
Mutual Trust \& Respect (MTR) & 2,818 & 2,826 & Tidak Kooperatif \\
Change Initiative (CI) & 2,605 & 2,616 & Pasif \\
Management Support (MS) & 2,71 & 2,733 & Tidak Mendukung \\
Acceptance (Acc) & 2,923 & 2,916 & Menerima \\
Managing Change & 2,703 & 2,719 & Tidak Terencana \\
\hline
\end{tabular}

jaan yang terdiri dari dosen dan tenaga kependidikan, jumlah responden dengan profesi sebagai dosen sebanyak 40 orang, sedangkan sisanya yaitu 81 orang adalah tenaga kependidikan. Fakultas A lebih didominasi dengan tenaga kependidikan selama 30-40 tahun.

Berdasarkan hasil perhitungan diperoleh skor OCR adalah dengan cara mencari mean yaitu dengan membagi total skor dengan jumlah item OCR sehingga didapatkan rentang angka yang bergerak 
diantara 1 hingga 4. Demikian pula untuk mendapatkan skor pada masing-masing aspek OCR, yaitu dengan membagi jumlah skor pada setiap aspek dengan jumlah item pada aspek tersebut sehingga rentang yang didapatkan pun sama, yaitu bergerak pada rentang antara 1 hingga 4. Lalu untuk menentukan kategori dari OCR dan masing-masing aspek, dilakukan perbandingan dengan norma kelompok. Hasilnya adalah seperti tabel 5.

Berdasarkan hasil penelitian didapatkan bahwa Universitas X secara umum masih belum siap untuk melakukan perubahan. Hal ini ditunjukkan dengan skor kesiapan organisasi untuk berubah (OCR) sebesar 2,784 yang berada dibawah norma kelompok sebesar 2,8. Adapun aspek-aspek yang masih perlu dikembangkan lagi, yaitu

1. Perception toward change effort ( SPTCE=2,919; Norma=2,93). Ini berarti bahwa para pegawai berdasarkan pengalaman mereka selama ini bekerja di universitas $\mathrm{X}$ masih merasa raguragu mengenai kemampuan organisasi untuk melakukan perubahan menuju world class university.

2. Vision of change $(\mathrm{SVOC}=2,826$; Norma $=2,841$ ). Kondisi ini berarti bahwa pegawai di Universitas $\mathrm{X}$ masih belum paham mengenai tujuan akhir yang ingin dicapai dan pola komunikasi mengenai perubahan tersebut yang masih belum efektif.

3. Mutual trust \& respect $(\mathrm{SMTR}=2,818$; Norma $=2,826$ ). Hal ini menunjukan bahwa pada aspek ini sikap dari para pegawai masih belum kooperatif terkait dengan perubahan yang terjadi di universitas $\mathrm{X}$.

4. Change initiative $(\mathrm{SCI}=2,605$; Norma=2,616). Change Initiative ini mengukur tentang keikutsertaan dari para pegawai guna menunjang perubahan yang tengah terjadi. Jika mengacu pada skor diatas yang berada dibawah norma, maka tampaknya para pegawai di universitas $X$ cenderung bersikap pasif dalam menghadapi perubahan.

5. Management support (SMS=2,71; Norma=2,733). Hasil ini menunjukan bahwa dukungan dari pihak pimpinan/manajemen terhadap proses perubahan masih belum optimal. Dukungan ini bisa berupa aturan, kebijakan, cara memimpin maupun kompensasi yang diterima oleh pegawai seiring dengan terjadinya proses perubahan.

6. Managing change $(\mathrm{SMC}=2,703$; Norma $=2,719)$, menunjukan bahwa perubahan yang terjadi di universitas $\mathrm{X}$ masih belum terencana dan berjalan secara efektif dan efisien.

Meski demikian, untuk aspek acceptance, yaitu aspek yang menunjukan penerimaan/penolakan terhadap perubahan yang terjadi di dalam organisasi, maka tampaknya secara umum para pegawai di universitas $\mathrm{X}$ menerima perubahan yang terjadi, meski tampaknya penerimaan tersebut lebih banyak berasal dari ketidakberdayaan para pegawai untuk menolak perubahan yang terjadi sehingga apa yang mereka lakukan sekedar menjalankan tugas semata.

Sementara itu, jika dibandingkan antara fakultas A dan fakultas B maka hasilnya lihat tabel 6 :

Setelah dilakukan penormaan terhadap hasil tersebut, maka didapatkan bahwa secara umum fakultas B yang merupakan fakultas percontohan universitas X lebih siap untuk berubah dibandingkan dengan fakultas A. Hal ini dengan melihat nilai skor OCR fakultas B yang berada pada angka 2,818 dan jika dibandingkan dengan norma OCR $(2,8)$ maka hasilnya berada diatas norma. Ini berarti bahwa fakultas $B$ telah siap untuk melakuan perubahan. Sementara di sisi lain, skor OCR fakultas A yang sebesar 
Tabel 6. Gambaran OCR \& aspekaspek OCR

\begin{tabular}{|c|c|c|}
\hline Aspek & Fakultas & Skor \\
\hline Organizational & $\mathrm{A}$ & 2,75 \\
\hline Change Readiness & B & 2,818 \\
\hline \multirow{2}{*}{$\begin{array}{l}\text { Perception Toward } \\
\text { Change Effort } \\
\text { (PTCE) }\end{array}$} & A & 2,92 \\
\hline & B & 2,918 \\
\hline \multirow{2}{*}{$\begin{array}{l}\text { Vision of Change } \\
(\mathrm{VoC})\end{array}$} & A & 2,71 \\
\hline & B & 2,932 \\
\hline \multirow{2}{*}{$\begin{array}{l}\text { Mutual Trust \& } \\
\text { Respect (MTR) }\end{array}$} & $\mathrm{A}$ & 2,82 \\
\hline & B & 2,815 \\
\hline \multirow{2}{*}{ Change Initiative (CI) } & A & 2,58 \\
\hline & $\mathrm{B}$ & 2,63 \\
\hline \multirow{2}{*}{$\begin{array}{l}\text { Management Support } \\
(M S)\end{array}$} & A & 2,7 \\
\hline & $\mathrm{B}$ & 2,722 \\
\hline \multirow{2}{*}{ Acceptance (Acc) } & $\mathrm{A}$ & 2,84 \\
\hline & B & 3,006 \\
\hline \multirow{2}{*}{ Managing Change } & A & 2,7 \\
\hline & B & 2,705 \\
\hline
\end{tabular}

2,75, berada dibawah norma OCR.

Hal ini menunjukan bahwa fakultas $A$ masih belum siap untuk melakukan perubahan.

Sementara itu untuk melihat perbe- daan kesiapan organisasi untuk berubah (organizational change readiness) antara fakultas A dan B, maka dilakukan pengujian statistik dengan menggunakan kriteria pengujian Mann-Whitney, yaitu tolak Ho jika $\mathrm{p}<0,05$. Hal ini mengingat data-data pada kedua fakultas tersebut tidak terdistribusi secara normal, data bersifat ordinal dan berasal dari dua kelompok yang berbeda. Setelah dilakukan perhitungan dengan menggunakan program software SPSS ver. 13.00 maka didapatkan hasil bahwa $p=0,128$. Ini berarti bahwa tidak ada perbedaan yang signifikan mengenai kesiapan organisasi untuk berubah baik pada fakultas A maupun fakultas B.

Hasil lengkap mengenai OCR dan aspek-aspek OCR setelah dilakukan uji beda dan dibandingkan dengan norma kelompok dapat dilihat pada tabel 7.

Jika melihat pada tabel 7 tersebut, maka didapatkan hasil bahwa terdapat 2 aspek yang berbeda secara signifikan antara fakultas A dan fakultas B, yaitu pada aspek vision of change dan acceptance. Aspek vision of change merupakan aspek yang menggambarkan sejauh mana

Tabel 7. Gambaran OCR, Uji Beda \& Norma Kelompok

\begin{tabular}{|c|c|c|c|c|}
\hline Aspek & Fakultas & $\begin{array}{l}\text { Uji Beda } \\
\text { Mann-Whitney } \\
(p<0,5)\end{array}$ & Norma Kel & Keterangan \\
\hline \multirow{2}{*}{$\begin{array}{l}\text { Organizational } \\
\text { Change Readiness } \\
\text { Perception Toward } \\
\text { Change Effort } \\
(P T C E)\end{array}$} & $\begin{array}{l}A=2,75 \\
B=2,818\end{array}$ & \multirow{2}{*}{$\begin{array}{l}\text { Tidak Berbeda } \\
(p=0,128) \\
\text { Tidak Berbeda } \\
(p=0,694)\end{array}$} & 2,8 & $\begin{array}{l}\text { Di bawah norma } \\
\text { Di atas norma }\end{array}$ \\
\hline & $\begin{array}{l}A=2,92 \\
B=2,918\end{array}$ & & 2,93 & Di bawah norma \\
\hline $\begin{array}{l}\text { Vision of Change } \\
\left(V_{o} C\right)\end{array}$ & $\begin{array}{l}A=2,71 \\
B=2,932\end{array}$ & $\begin{array}{l}\text { Berbeda secara } \\
\text { signifikan } \\
(\mathrm{p}=0,002)\end{array}$ & 2,841 & $\begin{array}{l}\text { Di bawah norma } \\
\text { Di atas norma }\end{array}$ \\
\hline $\begin{array}{l}\text { Mutual Trust \& } \\
\text { Respect (MTR) }\end{array}$ & $\begin{array}{l}A=2,82 \\
B=2,815\end{array}$ & $\begin{array}{l}\text { Tidak Berbeda } \\
(\mathrm{p}=0,791)\end{array}$ & 2,826 & \multirow{4}{*}{$\begin{array}{l}\text { Di bawah norma } \\
\text { Di bawah norma } \\
\text { Di bawah norma } \\
\text { Di atas norma } \\
\text { Di bawah norma } \\
\text { Di bawah norma } \\
\text { Di bawah norma } \\
\text { Di atas norma }\end{array}$} \\
\hline $\begin{array}{l}\text { Change Initiative } \\
\text { (CI) }\end{array}$ & $\begin{array}{l}A=2,58 \\
B=2,63\end{array}$ & $\begin{array}{l}\text { Tidak Berbeda } \\
(p=0,561)\end{array}$ & 2,616 & \\
\hline $\begin{array}{l}\text { Management } \\
\text { Support (MS) }\end{array}$ & $\begin{array}{l}A=2,7 \\
B=2,72\end{array}$ & $\begin{array}{l}\text { Tidak Berbeda } \\
(\mathrm{p}=0,248)\end{array}$ & 2,733 & \\
\hline Acceptance (Acc) & $\begin{array}{l}A=2,84 \\
B=3,006\end{array}$ & $\begin{array}{l}\text { Berbeda secara } \\
\text { signifikan } \\
(\mathrm{p}=0,028)\end{array}$ & 2,916 & \\
\hline Managing Change & $\begin{array}{l}A=2,7 \\
B=2,705\end{array}$ & $\begin{array}{l}\text { Tidak Berbeda } \\
(\mathrm{p}=0,505)\end{array}$ & 2,719 & $\begin{array}{l}\text { Di bawah norma } \\
\text { Di bawah norma }\end{array}$ \\
\hline
\end{tabular}


kemampuan pihak manajemen mengkomunikasikan visi yang ingin dicapai di masa yang akan datang kepada bawahannya sehingga semua pihak dapat memahami visi tersebut dengan jelas serta paham tentang perubahan yang diinginkan oleh organisasi. Sementara aspek acceptance menggambarkan sejauh mana bawahan menerima atau menolak terjadinya perubahan yang terjadi dalam organisasi.

Berdasarkan hasil tersebut, maka pada kasus di Universitas $\mathrm{X}$ (dengan sampel fakultas A dan fakultas B), keberhasilan suatu organisasi dalam hal ini sebuah fakultas jika dikaitkan dengan kriteria world class university, dipengaruhi oleh dua aspek dalam kesiapan organisasi untuk berubah (organizational change readiness), yaitu vision of change dan Acceptance. Vision of Change adalah aspek yang melihat sejauh mana perubahan-perubahan yang terjadi mampu dikomunikasikan dan dipahami oleh anggota dari organisasi. Sutanto (2008) mengatakan bahwa sebuah visi akan menjadi ketetapan dan kejelasan arah dari sebuah organisasi untuk maju. Tanpa visi yang realistis, upaya transformasi akan berubah menjadi kebingungan dan menjadi proyek yang tidak sesuai bahkan dapat mendorong organisasi ke arah yang salah atau tidak terarah sama sekali (Kotler,1995). Oleh karenanya, pemahaman yang menyeluruh dari para pegawai terhadap visi dari perusahaan/organisasi serta visi dari perubahan menjadi sangat penting (Sutanto, 2008). Hal ini lebih tampak terlihat pada fakultas B dimana visi fakultas di masa yang akan datang telah cukup jelas, yaitu to be world class faculty pada tahun 2026. Selain itu, langkah-langkah strategis yang harus dilakukan untuk bisa mencapai tujuan jangka panjang dari fakultas tersebut pun cukup jelas. Target-target yang dicapai pada setiap tahap telah jelas, misalnya saja pada tahun 2016 telah terakreditasi oleh lembaga akreditasi internasional EQUIS (Eroupean Quality Improvement System) sehingga untuk mencapai hal tersebut telah dilakukan pembenahan sistem prosedur kerja yang lebih mengacu kepada standar internasional tersebut. Atribut-atribut pro-mosi menuju world class faculty pun bisa dilihat di berbagai tempat di kampus fakultas B sehingga nuansa keinginan untuk berubah dapat dirasakan. Kegiatan-kegiatan seperti mendatangkan dosen tamu internasional pun cukup gencar dilaksanakan ataupun mengadakan seminar-seminar yang bersifat internasional. Kejelasan akan visi dan juga langkah-langkah yang harus dicapai ini membuat para pegawai di fakultas B paham tujuan fakultas di masa yang akan datang dan membawa mereka untuk mengarahkan segala tindakannya ke sana.

Kondisi berbeda pada fakultas A. Berdasarkan data-data di lapangan melalui hasil interview pada beberapa pegawai di fakultas A, didapatkan bahwa mereka merasa bahwa kriteria world class yang diharapkan oleh fakultas masih belum tergambar dengan jelas. Demikian pula dengan proses sosialisasi yang masih belum gencar baik itu pemasangan atributatribut yang menggambarkan tujuan akhir dari fakultas maupun upaya mengadakan forum diskusi guna memberikan kejelasan arah bagi pencapaian fakultas.

Faktor lainnya yang memberikan pengaruh bagi pencapaian organisasi dalam penelitian ini kriteria world class university, maka aspek Acceptance dalam organizational change readiness memegang peranan penting. Acceptance adalah suatu kondisi yang menggambarkan tentang sejauh mana tingkat penerimaan pegawai terhadap perubahan yang terjadi di dalam organisasi. Ciri telah terjadinya perubahan dalam organisasi adalah dengan melihat dampak dari terselesaikannya suatu pekerjaan, dalam hal ini pencapaian organisasi, maka reaksi dari pegawai terhadap proses perubahan menjadi hal yang sangat penting Eby, dkk., (2000). Jika melihat pada Universitas $\mathrm{X}$ maka didapatkan hasil bahwa para pegawai di fakultas B lebih bisa menerima perubahan- 
perubahan yang terjadi dibandingkan dengan fakultas A. Berdasarkan hasil interview dengan beberapa pegawai di fakultas A didapatkan data bahwa mereka cenderung untuk menolak terjadinya perubahan serta lebih pesimis dengan mengatakan bahwa world class university tidak lebih sekedar mimpi yang sulit diraih. Perubahan yang baru sekedar menambah beban bagi pekerjaan yang telah mereka dapatkan tanpa ditunjang dengan kompensasi yang memadai. Sikap-sikap seperti ini yang menjadi kendala bagi upaya perubahan yang dapat menunjang bagi performa yang lebih dalam mencapai visi world class university seperti yang terjadi pada fakultas A.

\section{SIMPULAN DAN SARAN}

Berdasarkan hasil penelitian terhadap dua fakultas di Universitas X terkait dengan kesiapan organisasi untuk berubah (organizational change readiness) maka dapat disimpulkan bahwa Universitas X sebagai organisasi masih belum siap untuk berubah terkait dengan visi universitas untuk menjadi world class university.

Aspek vision of change dan acceptance menjadi aspek penting yang menunjang bagi kesiapan untuk berubah tersebut. Aspek vision of change adalah aspek yang menggambarkan kejelasan dari suatu arah perubahan dan bagaimana perubahan tersebut dapat dipahami oleh para pegawai dan cara komunikasi yang efektif bagi organisasi untuk mensosialisasikan perubahan-perubahan tersebut. Pada Universitas $\mathrm{X}$ tampaknya keberhasilan dalam proses sosialisasi mengenai visi perubahan dan akan dibawa kemana perubahan tersebut akan menjadi penunjang bagi kesiapan organisasi dalam mencapai visinya sebagai world class university. Demikian pula dalam hal penerimaan terhadap perubahan (acceptance) yang merupakan salah satu aspek dalam kesiapan organisasi dalam menghadapi perubahan menjadi faktor lainnya. Semakin para pegawai di
Universitas $\mathrm{X}$ dapat menerima perubahan yang terjadi dalam organisasi, maka akan semakin mudah organisasi tersebut untuk melakukan transformasi menuju arah yang diinginkan.

Adapun saran terkait dengan pengembangan penelitian ini adalah dengan memperbanyak jumlah responden terkait dengan pengambilan data dengan mengambil sampel dari seluruh fakultas yang ada di Universitas X. Diharapkan hal ini dapat memberikan gambaran yang lebih nyata terkait dengan kesiapan universitas dalam menghadapi perubahan.

\section{DAFTAR PUSTAKA}

Armenakis, A. A., Harris, S. G., and Mossholder, K. W. 1993. Creating readiness for organizational change, Human Relations, 46 (June), 681703.

Armenakis, A. A., and Harris, S. G. 2002. Crafting a change message to create transformational readiness. Journal of Organizational Change Management, 15(Number 2), 169183.

Beckhardt, R. and Harris, R.T. 1987. Organizational transitions: managing complex change. Reading: Addison-Wesley.

Eby, Lilian T., Adams, Danielle M., Russel, Joyce E. A., and Gaby, Stephen H. 2000. Perceptions of organizational readiness: factor related to employees' reactions to the implementation of team based selling, Human Relation, 53(March), 419-442.

Gilmore, T., Shea, G., and Useem, M. 1997. Side effects of corporate culture transformations, Journal of Applied Behavioral Science, 33(June), 174-189.

Goodman, P.S., Devadas, R. and Hughson, T.L. 1988. Groups and productivity: analyzing the effectiveness of selfmanaging teams. In J.P. Campbell 
and R.J. Campbell (Eds.) Productivity in organizations: new perspectives from industrial and organizational psychology, pp. 295327. San Francisco: Jossey-Bass.

Kotter, J. 1995. Leading change: why transformation efforts fail. Harvard Business Review, 73 (March), 5967.

McManus, S.E., Russell, J.E.A., Freeman, D.M. and Rohricht, M.T. 1995. Factors related to employees' perceptions of organizational readiness for change. Paper presented International Journal of Management Perspectives ISSN: at the annual meeting of the Academy of Management, Vancouver, BC, Canada.

Rumelt, R.P. 1995. Inertia and transformation. In Montgomery, Cynthia A. (Eds.) Resources in an evolutionary perspective: towards a synthesis of evolutionary and resource-based approaches to strategy, pp. 101-132. Norwel : Kluwer Academic Publishers.
Smith, Ian. 2005. Achieving readiness for organizational change, Library Management, 26(June), 406-412.

Smith, Ian. 2005. Continuing professional development and workplace learning 11: managing the "people" side of organizational change, Library Management, 26(March), 152-155.

Stadtlander, Christian. 2006. Strategically balanced change: a key factor in modern management, Electronic Journal of Business Ethic and Organization Studies, 11(May), 1725.

Turner, D. and Crawford, M. 1998. Change Power: capabilities that drive corporate renewal. Sydney: Business and Professional Publishing. 